\title{
DETERMINAN PERILAKU SEKSUAL REMAJA DI SMA NEGERI 1 SIAK KECIL KABUPATEN BENGKALIS TAHUN 2017
}

\author{
Edi Rianto $^{1}$, Yuyun Priwahyuni ${ }^{2}$, Bayu Saputra ${ }^{3}$ \\ 1. Program Studi Ilmu Keperawatan, STIKes Hang Tuah Pekanbaru \\ Jalan Mustafa Sari No. 5 Tangkerang Selatan Pekanbaru \\ Email: edi_rianto@yahoo.com
}

\begin{abstract}
ABSTRAK
Remaja merupakan masa peralihan seorang anak menjadi seorang yang lebih dewasa, pada masa remaja, dimana juga dikatakan masa pancaroba yang sangat rentan dengan perilakuperilakuyang negatif, terlebih tentang perilaku seksual. Kurangnya pengetahuan dan arahan akan dapat menjerumuskan seorang remaja menuju kehancuran. Penelitian ini bertujuan untuk menjadi tolak ukur dalam mengetahui perilaku seksual remaja yang ada di SMA Negeri 1 Siak Kecil. Orang tua dan guru diharapkan dapat bekerja sama dalam memperhatikan perubahan perilaku pada seorang remaja, sehingga dapat menemukan langkah yang tepat dalam mengarahkan remaja tersebut. Metode yang digunakan adalahanalitik kuantitatif dengan desain cross sectional. Dengan cara menghubungkan faktor-faktor yang berhubungan dengan perilaku seksual remaja. Jumlah sampel dalam penelitian ini adalah 151 orang siswa. Hasil penelitian ini dapat disimpulkan terdapat beberapa faktor yang berpengaruh baik terhadap perilaku seksual remaja yaitu pendidikan seksual dan faktor keluarga. Sedangkan faktor media massa dan faktor teman sebaya memiliki pengaruh yang buruk terhadap perilaku seksual remaja di SMA Negeri 1 Siak Kecil.
\end{abstract}

Kata Kunci: Perilaku Seksual, Remaja.

\section{ABSTRACT}

Adolescence is a transition period for a child to become a more mature person, in adolescence, which is also said to be a transition period that is very vulnerable to negative behaviors, especially about sexual behavior. Lack of knowledge and direction can lead a teenager to destruction. This study aims to be a benchmark in knowing teenage sexual behavior in SMA Negeri 1 Siak Kecil. Parents and teachers are expected to work together in paying attention to behavioral changes in a teenager, so that they can find the right step in directing the teenager. The method used is quantitative analytic with cross sectional design. By connecting the factors related to adolescent sexual behavior. The number of samples in this study was 151 students. The results of this study can be concluded that there are several factors that have a good influence on adolescent sexual behavior, namely sexual education and family factors. While the factors of mass media and peer factors have a bad influence on adolescent sexual behavior in SMA Negeri 1 Siak Kecil.

Keywords : Sexual Behaviour, Adolescence. 


\section{PENDAHULUAN}

Masa remaja merupakan peralihan dari tingkat perkembangan anak-anak menuju dewasa. Pada tahap ini terjadi perubahan yang pesat terakit dengan fungsi reproduksi. Hal ini membuat terjadi perubahan pada fisik, mental dan peran remaja pada dunia sosial. Perilaku seksual remaja dapat digambarkan sebagai salah satu faktor yang perlu diperhatikan karena memberikan pengaruh pada perkembangan kehidpannya dimasa depan. Remaja berusaha mencapai kematangan baik berupa kemantangan fisik tetapi juga kematangan sosial dan psikologis (Widyatuti, Rahmawati \& Purnamaningrum, 2009).

Bentuk perilaku sekesual remaja yang menyimpang dan negatif yang dilakukan seperti petting, senggama, oral seks dan paling lebih dalam lagi yaitu remaja dapat serta menggunakan narkoba kemudia berlanjut melakukan hubungan seksua.. Penelitian yang dilakukan oleh Sarwono (2005), menemukan bahwa pelajar SMP di Bandung 10,53\% sudah melakukan ciuman bibir dan 3,86 \% sudah melakukan hubungan seksual pranikah.

Hasil penelitian Perkumpulan Keluarga Berencana Indonesia tahun (2010) menemukan data untuk wilayah Riau sekitar 38,73\% pelajar pernah melakukan hubungan seksual pada remaja putra. Dan sekitar 16,98 $\%$ remaja putri pernah melakukan hubungan seksual. Sedangkan proporsi usia, keloompok usia 10-14 tahun sebesar 13,57 \% remaja pernah melakukan melakukan hubungan seksual dan usia 15-18 tahun sebesar $29,46 \%$ ramaja pernah melakukan hubungan seksual.

Fenomena yang terjadi saat ini adalah banyaknya remaja yang bermesraan di tempat umum, bahkan tidak segan mereka berpacaran di sekolah, hal ini dibuktikan dengan banyaknya kasus yang dihadapioleh guru sekolah yang melihat secara langsung siswanya sedang berpacaran. Selain itu fenomena yang saat ini kerap terjadi yaitu hamil diluar nikah, hal ini diakibatkan oleh ketidakmampuan remaja dalam mengontrol perilaku seksualnya. Kontrol perilaku pada remaja sangatlah penting, hal ini mengingat kondisi psikologis remaja saat ini sangat rentan dan globalisasi dalam kemudahan akses informasi secara bebas (Mahmudah, 2016).

Dinas pendidikan dan kebudayaan kabupaten Bengkalis provinsi Riau pada tahun 2016 diketahui bahwa dari 39 jumlah SMA/SMK di dapatkan 25 kasus hamil diluar nikah, 34 kasus pernikahan dini dan 76 kasus tindakan seksusal di lingkungan sekolah. Hasil Penelitian Azimar (2013) menyatakan bahwa terdapat faktor-faktor yang mempengaruhi perilaku remaja terkait dengan seksual yaitu religious, sikap seksualitas, askses, paparan media informasi, pola perilaku dengan teman sebaya terkait seksual. 


\section{Sekolah Menengah Atas}

Negeri 1 Siak Kecil merupakan salah satu SMA Negeri yang ada di Kabupaten Bengkalis. Berdasarkan survey pendahuluan dan wawancara dengan pihak sekolah diketahui bahwa dalam tahun 2010-2014 terdapat 8 orang siswa yang berhenti sekolah akibat kejadian Hamil di Luar Nikah.

Penelitian ini akan melihat beberapa faktor yang mempengaruhi perilaku seksual remaja. Faktor yang akan di teliti adalah faktor pendidikan seksual, faktor keluarga, faktor teman sebaya dan faktor media massa. Pendidikan seksual yang tidak tepat yang didapatkan oleh siswa akan cenderuung membuat siswa penasaran dan lebih ingin melakukan hubungan seksual. Keluarga merupakan orang terdekat dari siswa, mempunyai peran kontrol dan pengawasan terhadap keseharian siswa dalam beraktifitas.

Faktor teman sebaya juga mempunyai peranan penting. Pada tahap remaja tahap perkembangan ialah teman sebaya dan lingkungan merupakan faktor yang mempengaruhi kehidupan remaja. Remaja akan lebih mudah melakukan curah informasi dan pendapat kepada teman sebaya ketimbang orang tua atau guru. Terakhir adalah faktor media massa, kemudahan akses informasi membuat remaja semakin mudah dalam menggali pengetahuan terutama tentang seksualitas. Tujuan penelitian ini adalah untuk mengetahui faktor-faktor yang berhubungan dengan perilaku seksual remaja di SMA N 1 Siak Kecil Kabupaten Bengkalis tahun 2017.

\section{METODE PENELITIAN}

Bentuk penelitian yang saat ini dilakukan adalah penelitian analitik kuantitatif dengan menggunakan desain penelitian cross sectional. Akan menghubungkan antara teman sebaya, media informasi, kondisi keluarga dan pendidikan seksual remaja dengan perilaku seksual remaja yang diamati dalam waktu yang bersamaan. Penelitian dilakukan pada bulan September 2018 dan dilakukan di SMA N 1 Siak Kecil.

Populasi pada penelitian ini berjumlah 242 orang. Pengambil sampel menggunakan teknik kuota random sampling sehingga didapatkan jumlah sampel yaitu 151 orang dan siswa yang dijadikan responden yaitu siswa yang duduk di kelas X dan XI.

Instumen penelitian yang digunakan berupa kuesioner isian yang dikembang oleh peneliti dan telah dilakukan uji validitas dan reliabilitas. Analisis data yang digunakan yaitu univariat dan bivariat. Univariat untuk melihat distribusi frekuensi dari Perilaku sekual remaja, pendidikan seksual, kondisi keluarga, teman sebaya dan media sosial. Sedangkan untuk bivariat yaitu hubungan antara perilaku seksual dengan pendidikan seksual, kondisi keluarga, teman sebaya dan media massa. 


\section{HASIL PENELITIAN}

Hasil peneltian ini dapat dilihat sebagai berikut:

Tabel 1. Distribusi Frekuensi Pendidikan seksual, media massa, teman sebaya, faktor keluarga pada Remaja di SMAN 1 Siak Kecil

\begin{tabular}{|c|c|c|c|}
\hline No. & Pendidikan Seksual & Frekuensi & $\%$ \\
\hline 1. & Baik & 87 & 57,7 \\
\hline \multirow[t]{2}{*}{2.} & Buruk & 64 & 42,4 \\
\hline & Total & 151 & 100 \\
\hline No. & Media Massa & Frekuensi & $\%$ \\
\hline 1. & Baik & 67 & 44,4 \\
\hline \multirow[t]{2}{*}{2.} & Buruk & 84 & 55,6 \\
\hline & Total & 151 & 100 \\
\hline No. & Teman Sebaya & Frekuensi & $\%$ \\
\hline 1. & Baik & 59 & 39 \\
\hline \multirow[t]{2}{*}{2.} & Buruk & 92 & 61 \\
\hline & Total & 151 & 100 \\
\hline No. & Faktor Keluarga & Frekuensi & $\%$ \\
\hline 1. & Baik & 112 & 74 \\
\hline \multirow[t]{2}{*}{2.} & Buruk & 39 & 55,6 \\
\hline & Total & 151 & 100 \\
\hline No. & Perilaku Seksual & Frekuensi & $\%$ \\
\hline 1. & Positif & 82 & 54,5 \\
\hline \multirow[t]{2}{*}{2.} & Negatif & 69 & 45,5 \\
\hline & Total & 151 & 100 \\
\hline
\end{tabular}

Berdasarkan tabel 1 dapat diketahui mengenai gambaran frekuensi mengenai tiap-tiap varibel yang diteliti. Sebagian besar responden memiliki pengaruh baik yang cukup besar pada pendidikan seksual yaitu sekitar $57,6 \%$. Untuk faktor media massa sebagian besar menggambarkan pengaruh yang buruk yaitu 55,6\%. Kemudian untuk teman sebaya menggambarkan bahwa lebih dari separuh remaja menyatakan teman sebaya memberikan pengaruh yang buruk terhadap perilaku seksual pada remaja. Dan yang terakhir sebagian besar remaja menyatakan keluarga memberikan dukungan yang positif yaitu sekitar 74,2\%.

Pada variabel dependen yaitu perilaku seksual remaja. Tabel 1 menggambarkan bahwa sebagian besar remaja memiliki perilaku yang positif. Namun masih banyak juga yang berperilaku negatif yaitu sebesar 45,5\%. Hasil penelitian analisis bivariat adalah sebagian berikut. 
Tabel 2 Hubungan Pendidikan Seksual dengan Perilaku seksual remaja.

\begin{tabular}{lcccc}
\hline Pendidikan & \multicolumn{2}{c}{ Perilaku Seksual } & \multirow{2}{*}{ Total } & \multirow{2}{*}{ p value } \\
\cline { 2 - 3 } \multicolumn{1}{c}{ Seksual } & Positif & Negatif & & \\
\hline Baik & 47 & 40 & 87 & \\
Buruk & 34 & 30 & 63 & 0,002 \\
\hline Total & $\mathbf{8 1}$ & $\mathbf{7 0}$ & $\mathbf{1 5 1}$ & \\
\hline
\end{tabular}

Berdasarkan tabel 2 diketahui bahwa hasil uji chi square diperoleh nilai $\mathrm{p}$ sebesar 0,002. Sehingga dapat disimpulkan terdapat hubungan yang signifikan antara faktor pendidikan dengan perilaku seksual remaja.

Tabel 3 Hubungan Media Massa dengan Perilaku seksual remaja.

\begin{tabular}{lcccc}
\hline \multicolumn{1}{c}{ Pendidikan } & \multicolumn{2}{c}{ Perilaku Seksual } & \multirow{2}{*}{ Total } & \multirow{2}{*}{ value } \\
\cline { 2 - 3 } \multicolumn{1}{c}{ Seksual } & Positif & Negatif & & \\
\hline Baik & 39 & 28 & 67 & \\
Buruk & 42 & 42 & 84 & \multirow{2}{*}{0,003} \\
\hline Total & $\mathbf{8 1}$ & $\mathbf{7 0}$ & $\mathbf{1 5 1}$ & \\
\hline
\end{tabular}

Berdasarkan tabel 3 diketahui bahwa hasil hasil uji chi square diperoleh nilai $\mathrm{p}$ sebesar 0,003. Dapat disimpulkan bahwa terdapat hubungan yang signifikan antara faktor penggunaan media massa terhadap perilaku seksual remaja.

Tabel 4 Hubungan Teman Sebaya dengan Perilaku seksual remaja

\begin{tabular}{lcccc}
\hline \multicolumn{1}{c}{$\begin{array}{c}\text { Pendidikan } \\
\text { Seksual }\end{array}$} & \multicolumn{2}{c}{ Perilaku Seksual } & \multirow{2}{*}{ Total } & \multirow{2}{*}{ v value } \\
\cline { 2 - 3 } & Positif & Negatif & & \\
\hline Baik & 32 & 27 & 69 & \\
Buruk & 50 & 42 & 92 & 0,003 \\
\hline Total & $\mathbf{8 2}$ & $\mathbf{6 9}$ & $\mathbf{1 5 1}$ & \\
\hline
\end{tabular}

Berdasarkan tabel 4 diketahui bahwa hasil uji chi square diperoleh nilai $\mathrm{p}$ sebesar 0,003. Sehingga dapat disimpulkan terdapat hubungan yang signifikan antara pengaruh teman sebaya dengan perilaku seksual pada remaja.

Tabel 5 Hubungan Kondisi Keluarga dengan Perilaku seksual remaja.

\begin{tabular}{lcccc}
\hline \multicolumn{1}{c}{$\begin{array}{c}\text { Pendidikan } \\
\text { Seksual }\end{array}$} & \multicolumn{2}{c}{ Perilaku Seksual } & \multirow{2}{*}{ Total } & \multirow{2}{*}{ p value } \\
\cline { 2 - 4 } & Positif & Negatif & & \\
\hline Baik & 69 & 43 & 112 & \\
Buruk & 13 & 26 & 39 & 0,002 \\
\cline { 1 - 4 } Total & $\mathbf{8 2}$ & $\mathbf{6 9}$ & $\mathbf{1 5 1}$ & \\
\hline
\end{tabular}


Berdasarkan tabel 5 diketahui bahwa hasil uji chi square diperoleh nilai $\mathrm{p}$ sebesar 0,002. Sehingga dapat

\section{PEMBAHASAN}

Berdasarkan hasil uji square diperoleh nilai $\mathrm{p}$ lebih rendah dari nilai $\alpha$ yaitu 0,005 . Sehingga hasil penelitian ini menyatakan bahwa terdapat hubungan yang signifikan antara faktor pendidikan seksual, media massa, teman sebaya dan faktor keluarga dengan perilaku seksual remaja di SMAN 1 Siak kecil.

Faktor pendidikan seksual merupakan suatu bentuk tindakan dalam penerangan dan pengajaran terkait dengan permasalahan perilaku seksual yang dapat digambarkan dalam bentuk naluri seks dan hubungan seksual. Dapat disimpulkan setiap remaja yang menginjak usia dewasa dan dapat paham dalam menjalani nilai-nilai kehidupan. Ramaja memahami permasalahan kehidupan dan tindakan-tindakan yang dilarang dan diperbolehkan. Remaja dituntut mampu menerapkan perilaku keagmaan sebagai akhlak, mengontrol nafsu dan tidak mengikuti bentuk-bentuk hedonism terkait dengan perilaku seksual remaja (Suraji, 2008).

Pendidikan seksual yang baik menggambarkan secara keseluran mengenai perilaku seksual dan dampak melakukan seks pra nikah. Penelitian yang dilakukan Syafrudin (2008), pemahaman pengetahuan yang dipahami oleh remaja secara disimpulkan terdapat hubungan yang signifikan antara kondisi keluarga dengan perilaku seksual pada remaja.

tidak lengkap akan lebih membahayakan jika dibandingkan dengan pemahaman remaja yang tidak mengetahui sama sekali. Hal ini disebabkan oleh karena pengetahuan dibentuk dari faktor dari dalam atau internal yaitu bagaimana individu berespon terhadap suatu pengetahuan baru kemudian secara ekternal remaja akan mengubah bentuk perilaku menjadi semakin baik dalam kehidupan sehari-hari. Prayitno (2008) menyatakan bahwa bentuk pengetahuan yang ideal akan membuat responden mengerti dan memahami mengenai perilaku seks pranikah.

Penggabuungan dengan pendidikan agama pada remaja juga turut memberikan pengaruh pada perilaku remaja. Kresnawati (2007), menyatakan bahwa terdapat hubungan yang signifikan antara kecerdasan spiritual dengan kemampuan pemecahan masalah ketika remaja mengalami permasalahan seksual dan mampu melakukan kontrol terhadap nafsu dan syahwat. Hasil analisa secara deskriptif diketahui bahwa memahami keagamaan menggambarkan remaja akan dapat melakukan kontrol terhadap perilaku menyimpang. Ketaatan dalam beribadah akan membantu remaja memahami bahwa tindakan menyimpang akn memberikan 
hukuman secara nilai agama terkait dengan dosa dan beban melakukan secara spiritual. Kemudian selanjutnya peran keluarga yaitu orang tua harus memberikan pemahaman agama yang kuat kepada remaja. Pemhaman keagmaan harus ditanamkan sejak dini dan dipraktikan setiap hari oleh remaja dan orang tua setiap hari. Selain itu peran orang tua dalam mengontrol dan mengendalikan perilaku remaja terkait seksual remaja yang menyimpang.

Media massa merupakan alat atau fasilitias yang dipakai unutk mengemukakan pesan dari komunikator pada khalayak, sedangkan pengertian medaia massa sendiri alat yang dipakai dalam penyampaian pesan dapat menggunakan alat komunikasi seperti majalah, novel, film dan terkahir adalah televisi. Menurut Cangara (2008) kemudahan akses akan informasi saat ini memberikan dampak negatif yang cukup besar terhadap remaja, tidak adanya pengawasan akan memudah kan remaja dalam mengakses informasi terkait dengan seksual dan pornografi. Terkadang saat ini perilaku yang dilakukan remaja lebih besar mereka contoh dan ditiru dari media massa dari pada meraka pelajari dari orang tua dirumah atau guru disekolah.

Penelitian yang dilakukan Syafrudin, (2008) menyatakan bahwa saat ini remaja lebih memilih mencari informasi sendiri melaui media informasi seperti majalah, buku, atau internet terkait masalah seksual dibandingkn ia membicarakan dengan orang tua. Hal ini menyebabkan remaja terkadang justru mendapatkan penjelasan yang salah dansalah pula dalam memahami suatu pengetahuan. Remaja justru lebih sering dalam melakukan akses media pornografi dibandingkan pengetahuan seksual yang sehat. Hasil studi Pustaka Komunikasi FISIP UI (2005) menyatakn bahwa saat ini remaja yang telah melakukan hubungan seksual hal ini disebakan oleh kemudahan dalam akses media pornografi, dan pemahaman yang salah dalam menerima informasi terkait pornografi.

Beberpaa penelitian menunjukkan bahwa remaja harus mendapatkan informasi dan pemahaman yang positif dan sehat terkait dengan organ reproduksi dan perkembangan reproduksi, yang harusnya diberikan oleh guru, orang tua dan petugas kesehatan. Bukan berasal dari media-media informasi yang tidak jelas. (Saifuddin dan Hidayana, 1999). Selanjutnya teman sebaya akan turut memberikan perilaku yang meyimpang pada remaja terkait seksual (Hady, 2009). Akibat dari hal ini maka diperlukan adanya jaminan bahwa remaja mendapatkan informasi yang akurat dan baik dan remaja mampu memilah informasi yang sifatnya menyimpang dengan informasi yang positif dan mendukung perkembangan perilaku seksual remaja (Anonim, 2009) 
Faktor teman sebaya dengan perilaku seksual remaja, pada tahap perkembangan remaja pengaruh lingkungan sangat penting dan sangat memberikan dampak yang besar bagi pekembangan remaja. Teman sebaya merupakan lingkungan yang paling memberikan pengaruh, karena remaja lebih memilih mengikuti teman sebaya dari pada orang tua ataupun guru.

Penelitian ini sejalan dengan peneltian yang dilakukan oleh Rusmayanti (2010) yang menyatakan bahwa perilaku seksual remaja yang menyimpang diakibatkan oleh pergaulan dengan teman-teman sekitarnya. Dan terkait informasi awal remaja kebanyakan mendapat informasi mengenai seksual dari teman-teman. Tren saat ini menemukan bahwa remaja lebih banyka menghabiskan waktu diluar rumah dengan teman-temannya dan biasanya mereka membentuk suatu kelompok dan menggambarkan identitas mereka sebagai kelompok remaja. Peneltian yang dilakukan oleh Tarwoto (2010) menyatakan sikap, pembicaraan minat dan penampilan remaja merupakan cerminan dari siapa teman pergaulannya dan sangat memberikan pengaruh dalam keseharainnya. Sehingga kepada ornag tua dan guru disarankan unutk dapat melakukan pemantauan dan mengetahui siapa yang menjadi teman pergaulan dan kemana remaja menghabiskan waktu luang yang ia miliki.
Pengaruh faktor keluarga dengan perilaku seksual remaja. Sebagaimana diketahui keluarga adalah unit terkecil dari masyarakat yang terdiri atas kepala keluarga dan beberapa orang yang berkumpul dan tinggal di suatu tempat dibawah atap yang sama dalam keadaan yang salin ketergantungan (Effendi, 2005). Keluarga seharusnya merupakan orang-oran terdekat seorang remaja, dalam keluarga remaja harusnya dapat diawasi dengan baik, apabila anggota keluarga memiliki hubungan dan komunikasi yang harmonis, sehingga dapat mengawasi perilaku seksual remaja.

Orang tua sangat memegang peranan penting dalam mendukung perkembangan perilaku seksual remaja, ayah dan ibu berkewajiban menjaga keharmonisan hubungan antar sesama anggota keluarga. Hal ini akan sejalan dengan perkembangan emosional remaja dengan perkembangan kepribadian remaja dan sebaliknya, hubungan yang tidak harmonis akan mengganggu komunikasi dalam keluarga, dan remaja cenderung melarikan diri dari kontak dengan keluarga. Keluarga yang tidak sempurna seperti perceraian, kematian, dan keluarga dengan kondisi ekonomi rendah, hal ini turut memberikan dampak pada perkembangan jiwa remaja.

Keterbatasn dalam peneltian adalah begitu sulitnya unutk mendapatkan kepercayaan dari remaja sehingga ia mampu mengisi kuesioner dengan jujur. Sehingga 
peneliti diharuskan unutk mampu membangun kepercayaan pada remaja.

\section{SIMPULAN}

Perilaku seksual merupakan serangkaian aktifitas kegiatan dan aktifiatas yang menggambarkan bagaimana remaja bersepon dan memberikan reaksi terhadap suatu stimulus dalam hal ini merupakan seksual. Banyak faktor yang mempengaruhi bagaimana remaja mampu berperilaku positif dalam hal seksual.

Keempat faktor yang telah diteliti yaitu pengetahuan seksual, penggunaan media massa, teman sebaya, keluarga memberikan hubungan yang sginifikan terhadap perilaku seksual remaja. Sebagaimana diketahui bahwa kekempat aspek tersebut merupakan faktor eksternal dari diri remaja. Sehingga orang tua, guru dan keluarga harus memberikan perhatian khusus pada lingkungan eksternal remaja.

\section{DAFTAR PUSTAKA}

Widyatuti, R, Rahmawati M \& Purnamaningrum.(2009).

Hubungan Antara Pengetahuan Seksualitas Dan Religiusitas Dengan Intensi Perilaku Seksual Pranikah Pada Mahasiswi

http://etd.library.ums.ac.id/go.p hp?id=jtptums-gdl-s1-2007citraanggi-4378. Diakses pada tanggal 19 Januari 2017
Sarwono W.S. (2005). Psikologi Remaja. Jakarta: Grafindo Persada

Mahmadun A.S. (2016). Karakteristik Perilaku dan Pribadi padaMasa Remaja http://akhmadsudrajat.wordpre ss.com/2016/03/05/karakteristi k-perilakudan-pribadi-padamasa-remaja. Diakses Tanggal 12 Januari 2017.

Azimar R. 2013. Perbedaan Perilaku Terhadap Hubungan Seksual Pranikah Ditinjau Dari Religiusitas.

http://etd.library.ums.ac.id/go.p hp?id=jtptumsgdl-s1-2013-

rabiatulad-5614. Diakses pada tanggal 7 Februari 2017.

Dinas Pendidikan. (2013). Data Sekolah menengah atas Kota Pekanbaru.

Suraji A., (2006). Faktor-faktor yang mempengaruhi Perilaku Seksual Remaja Di Jawa Tengah: Implikasinya Terhadap Kebijakan Dan Layanan Kesehatan Seksual Dan Reproduksi. Makara Kesehatan. vol.10. no.1 juni 2006: $29-40$

Syafrudin. (2008). Remaja Dan Hubungan Seksual Pranikah http://id.shvoong.com/medicin e-and-health/1799376-remajadan-hubungan seksualpranikah/ . Diakses pada tanggal 21 Januari 2017 
Prayitno M. A. (2008). Hubungan

Antara Pengetahuan

Seksualitas Dan Religiusitas

Dengan Intensi Perilaku

Seksual Pranikah Pada

Mahasiswi

http://etd.library.ums.ac.id/go.p

hp?id=jtptums-gdl-s1-2008-

citraanggi-4378. Diakses pada tanggal 19 Januari 2017.

Kresnawati. (2007). Hubungan antara kecerdasan spiritual dengan kemampuan pemecahan masalah pada remaja.

http://etd.library.ums.ac.id/go.p hp?id=jtptums-gdl-s1-2007-

kresnawati5530. Diakses pada tanggal 7 Februari 2017.

Hady R. (2008). Pendidikan Seks Upaya Preventif Perilaku Seksual Pranikah http://.wordpress.com/2009/02/ 24/pendidikan-seksupayapreventif-perilakuseksual-pranikah/. Diakses pada Tanggal 13 Januari 2017.

Saifuddin R \& Hadiyana T.(2006). Remaja Usia 15 - 18 Tahun Banyak Lakukan Perilaku Seksual

Pranikah.http://www.ugm.ac.id /index.php?page $=$ rilis\&artikel $=$ 1659. Diakses Tanggal 6 Januari 2017

Rusmayanti D.A., (2008). Pengaruh Pergaulan Bebas Dan Vcd Porno Terhadap Perilaku Remaja Di Masyarakat. http://kbi.gemari.or.id/beritadet ail.php?id=2569 Diakses Tanggal 29 November 2017

Tarwoto T. 2006. Perilaku seks di surakarta.

http://elfarid.multiply.com/jour nal/item/306 Diakses 7 Januari 2017.

Tarwoto R.(2010). Pengaruh Pendidikan Kesehatan Seksual Terhadap Pengetahuan dan Sikap Remaja dalam Upaya Pencegahan Penularan HIV/AIDS di Kodia Yogyakarta. Berita Kedokteran Masyarakat XIX/IXI - 60; UGM Yogyakarta.

Effendi M. A. 2007. Hubungan Antara Pengetahuan Seksualitas Dan Religiusitas Dengan Intensi Perilaku Seksual Pranikah Pada Mahasiswi http://etd.library.ums.ac.id/go.p hp?id=jtptums-gdl-s1-2007citraanggi-4378. Diakses pada tanggal 19 Januari 2012. 